\title{
ДІАХРОНІЧНА ВЕРИФІКАЦІЯ ФОНОЛОГІЧНИХ, ГРАМАТИЧНИХ І СЕМАНТИЧНИХ ПЕРЕХОДІВ НОСТРАТИЧНОГО ЕТИМОНУ *НUКА «ОКО, БАЧИТИ»
}

\author{
Корольова А. В., Капранов Я. В.
}

\section{ВСТУП}

Сучасний етап перевірки гіпотези ностратичної спорідненості мов пропонує різні методики виявлення ступенів масового споріднення, які так чи інакше продовжують застосовувати техніку діахронічної інтерпретаиї О. Семереньї ${ }^{1}$. За словами Л.П. Дронової, специфіка останньої процедури полягає в тому, що вона послуговується не реальним мовним субстратом, необхідним для виконання реконструкції, а оперує лише архетипами для занурення в хронологічно віддалені етапи прамовного стану ${ }^{2}$. I хоча диференційна ознака архетипу, як підкреслює Г.А. Климов, «виконує гносеологічну функцію - історично підтвердити реально засвідчені мовні форми $<\ldots>{ }^{3}$, проте саме цей релікт $\epsilon$ тим діахронічним утворенням, який дає змогу вивчати дуже давні прамовні стани і простежити моделі синхронічних i/aбо діахронічних переходів на фонологічному, морфонологічному і семантичному рівнях.

У зв'язку 3 цим пропонуємо новий термін «діахронічна верифікація» на позначення процедури виявлення ступенів споріднення мов, для яких реконструйовано ностратичні етимони і їхні когнітивні структури - архетипи. За філософським енциклопедичним словником, верифікація - це загальнонауковий принцип філософії науки, згідно 3 яким визначається істинність або хибність наукових теорій, 3'ясовується, які емпіричні складники наукових теорій підтверджують або спростовують теоретичну складову частину науки, а головне те, чи мають раціонально-пізнавальний смисл «метафізичні» припущення у філософії науки ${ }^{4}$.

${ }_{1}^{1}$ Семереньи О. Введение в сравнительное языкознание. Москва, 1980. С. 13.

2 Дронова Л.П. Синхрония и диахрония: отложенная встреча? Вестник Томского государственного университета. Филология. Томск, 2009. № 3(7). С. 117.

${ }_{3}^{3}$ Климов Г.А. Реконструкция и диахроническая интерпретация в компаративистике. Вопросы языкознания. Москва, 1988. № 3. С. 10.

${ }^{4}$ Философский энциклопедический словарь / ред.-сост. Е.Ф. Губский и др. Москва : ИНФРА-М, 2012. 570 с. 
Діахронічна верифікація - це процедура перевірки фонологічних, морфонологічних і семантичних переходів у ностратичному матеріалі 3 метою фіксації ступенів масового споріднення мов за тріадою тип вид - відношення.

Процедура діахронічної верифікації - це відповідний методологічний алгоритм, який дослідник виконує в три етапи: перший етап - верифікація на макрорівні за двома напрямами: а) вертикальним одновекторним напрямом, що передбачає виявлення переходів ностратичного архетипу і архетипу(-ів) на рівні сім'ї; б) за горизонтальним багатовекторним напрямом, де встановлюється зв'язок архетипів на рівні сім'ї; другий етап - мікрорівень із чотирма напрямами: а) вертикальним одновекторним напрямом прамовного рівня - встановлюється залежність архетипу на рівні сім'ї і архетипу(-ів) на рівні груп(-и); б) горизонтальним багатовекторним напрямом прамовного рівня - простежується зв'язок архетипів на рівні груп; в) вертикальним одновекторним напрямом мовного рівня - зв'язок архетипу на рівні сім'ї i/aбо архетипу(-ів) на рівні груп(-и) і мовного(-их) відповідника(-ів); г) горизонтальним багатовекторним напрямом мовного рівня - зв'язок мовних відповідників; третій етап - наскрізний рівень за двома напрямами: а) вертикальним № 1 - залежність/зв’язок ностратичного архетипу i архетипу(-ів) на рівні груп(-и); б) вертикальним № 2 - залежність/зв'язок ностратичного архетипу і мовних відповідників.

Зауважимо, що в межах цієї статті діахронічна верифікація переходів ностратичного етимону *huКа «око, бачити» буде здійснена на макро- і мікрорівнях.

\section{1. Фіксація фонологічних, морфонологічних і семантичних переходів у матричному форматі}

Перша стадія - побудова матриці фонологічних, морфонологічних i семантичних переходів, в якій буде зафіксовано по вертикалі фонетичні, морфонологічні та семантичні процеси, а по горизонталі мовні й/або прамовні відповідники.

На першій процедурі першої стадії будуємо матрицю для ностратичної статті (ностратичного матеріалу) 3 порожніми клітинами.

На другій процедурі першої стадії заносимо по вертикалі фонетичні, морфонологічні та семантичні переходи.

На третій процедурі першої стадії заносимо по горизонталі мовні й/або прамовні відповідники, представлені в аналізованій ностратичній статті. 
Нижче подаємо характеристику фонологічних, морфонологічних $\mathrm{i}$ семантичних переходів ностратичного матеріалу - архетипів різних рівнів.

Ностр *НиКа відображає фонетичні процеси вокалізму: 1) процеси за піднесенням: якщо на початку загальної морфемної структури (далі - ЗМС) фіксуємо верхній (*u: НА *HuKa) зсув, то в кінці ЗМС - нижній (*a: НА *HuKa); 2) процеси за рядом: якщо на початку ЗМС фіксуємо задній (*u: НА *HuKa) зсув, то в кінці ЗМС середній (*a: НА *НuКа); 3) процеси лабіалізації/делабіалізації: якщо на початку ЗМС фіксуємо лабіалізацію (*u: НА *HuKa), то в кінці ЗМС - делабіалізацію (*a: НА *НuKa); фонетичні процеси консонантизму: 1) процеси за місцем творення: якщо на початку ЗМС фіксуємо глоталізацію (*h: НА *HuКа), то в кінці веляризацію (*k: НА *НuКа); 2) процеси за участю голосу й шуму: на початку (*h: НА *HuKa) і в кінці (*k: НА *HuKa) 3МС фіксуємо глухість; морфонологічні процеси: 1) закон про трьохелементну структуру, 2) закон про закритий склад (HA *HuK- - HA *CVC-); семантичні процеси: 1) APX «орган зору»: *НuКа «око»; 2) APX «зорова здатність»: *НuКа «бачити».

Алт *uka-, що відображає фонетичні процеси вокалізму: 1) процеси за піднесенням: якщо на початку ЗМС фіксуємо верхній (*u: Алт *uka-), то в кінці ЗМС - нижній (*a: Алт *uka-); 2) процеси за рядом: якщо на початку ЗМС фіксуємо задній (*u: Алт *uka-), то в кінці ЗМС - середній (*a: Алт *uka-); 3) процеси лабіалізації/делабіалізації: на початку ЗМС фіксуємо лабіалізацію (*u: Алт *uka-), то в кінці 3МС - делабіалізацію (*a: Алт *uka-); фонетичні процеси консонантизму: 1) процеси за місцем творення: фіксуємо веляризацію (*k: Алт *uka-); 2) процеси за участю голосу й шуму: фіксуємо глухість (*k: Алт *uka-); морфонологічні процеси: 1) закон про двохелементну структуру, 2) закон про закритий склад (Алт *uk- - Алт *VC-); семантичні процеси: 1) APX «зорова здатність»: Алт *uka- «помічати»; 2) АРX «розумова здатність»: Алт *uka- «розуміти».

Монг *uka- «помічати» відображає фонетичні процеси вокалізму: 1) процеси за піднесенням: якщо на початку ЗМС фіксуємо верхній (*u: *uka-) зсув, то в кінці ЗМС - нижній (*a: *uka-); 2) процеси за рядом: якщо на початку ЗМС фіксуємо задній (*u: *uka-) зсув, то в кінці ЗМС - середній (*a: *uka-); 3) процеси лабіалізації/делабіалізації: якщо на початку ЗМС фіксуємо лабіалізацію (*u: *uka-), то в кінці ЗМС - делабіалізацію (*a: *uka-); фонетичні процеси консонантизму: 1) процеси за місцем творення: фіксуємо веляризацію (*k: *uka-); 2) процеси за участю голосу й 
шуму: фіксуємо глухість (*k: *uka-); морфонологічні процеси: 1) закон про двохелементну структуру, 2) закон про закритий склад (Монг *uk- - Монг *VC-); семантичні процеси: APX «зорова здатність»: Монг *uka- «помічати».

Тюрк *uk(a))- відображає фонетичні процеси вокалізму: 1) процеси за піднесенням: якщо на початку ЗМС фіксуємо верхній $(* \mathrm{u}: * \mathbf{u k}(\overline{\mathrm{a}})-)$ зсув, то в кінці ЗМС - нижній $\left.\left(* \mathrm{a}:{ }^{*} \mathrm{uk}(\overline{\mathbf{a}})-\right) ; 2\right)$ процеси за рядом: якщо на початку ЗМС фіксуємо задній (*u: *uk(a) -) зсув, то в кінці ЗМС - середній $(* a: * * u k(\overline{\mathbf{a}})-) ; 3)$ процеси лабіалізації/делабіалізації: на початку ЗМС фіксуємо лабіалізацію $(* \mathrm{u}: * \mathbf{u k}(\overline{\mathrm{a}})-)$, то в кінці ЗМС - делабіалізацію (*a: *uk( $\overline{\mathbf{a}})-)$; фонетичні процеси консонантизму: 1) процеси за місцем творення: фіксуємо веляризацію $\left({ }^{*} \mathrm{k}: * \mathrm{k}(\overline{\mathrm{a}})-\right)$; 2$)$ процеси за участю голосу й шуму: фіксуємо глухість (*k: *uk(ā)-); морфонологічні процеси: 1) закон про двохелементну структуру, 2) закон про закритий склад (Тюрк *uk(ā)- - Тюрк *VC(V)-); семантичні процеси: 1) APX «слухова здатність»: Тюрк *uk( $\overline{\mathrm{a}})$ - «слухати»; 2) APX «фізична здатність»: Тюрк *uk(a) $)-:$ «піднімати».

Афр *Hwq- відображає фонетичні процеси консонантизму: 1) процеси за місцем творення: якщо на початку ЗМС фіксуємо глоталізацію (*h: *Hwq-), в середині ЗМС лабіалізацію (*w: *Hwq-), то в кінці $3 \mathrm{MC}$ - веляризацію (*q: *Hwq-); 2) процеси за участю голосу й шуму: якщо на початку ЗМС фіксуємо глухість (*h: *Hwq-), в середині ЗМС - дзвінкість (*w: *Hwq-), то в кінці ЗМС - глухість (*q: Hwq-); морфонологічні процеси: 1) закон про трьохелементну структуру, 2) закон про закритий склад (Афp *Hwq- - Афp *CCC-); семантичні процеси: АРХ «розумова здатність»: Афp *Нwq- «знати».

IC *h"ek"-/*heuk- відображає фонетичні процеси вокалізму: 1) процеси за піднесенням: фіксуємо середній (*e: *h" $\mathrm{ek}^{\mathrm{u}}-/{ }^{*}$ heuk-) зсув; 2) процеси за рядом: фіксуємо передній (*e: *h" $k^{\mathrm{u}}-/{ }^{\mathrm{N}}$ heuk-) зсув; 3) процеси лабіалізації/делабіалізації: фіксуємо делабіалізацію (*e: *hu $\left.{ }^{u} k^{u}-/ * h e u k-\right)$; фонетичні процеси консонантизму: 1) процеси за місцем творення: якщо на початку ЗМС фіксуємо глоталізацію

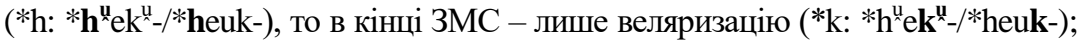
2) процеси за участю голосу й шуму: на початку (*h: *h" $\left.{ }^{\mathrm{u}} \mathrm{k}^{\mathrm{u}} /{ }^{*} / \mathrm{heuk}-\right)$ i в кінці (*k: *h" $\mathrm{h}^{\mathrm{u}} \mathrm{k}^{\mathrm{u}} /{ }^{*}$ heuk-) ЗМС фіксуємо глухість; морфонологічні процеси: 1) закон про трьохелементну структуру, 2) закон про закритий склад (IC * $\mathrm{h}^{\mathrm{u}} \mathrm{e} \mathrm{k}^{\mathrm{u}}-/{ }^{*} \mathrm{heuk}-\mathrm{IC}{ }^{*} \mathrm{CVC}-/{ }^{*} \mathrm{CVVC}-$ ); семантичні процеси: 1) АРX «орган зору»: IC * $h^{\mathrm{u}} \mathrm{ek}^{\mathrm{u}}-/{ }^{*}$ heuk- «око»; 2) APX «зорова здатність»: IC *h" $\mathrm{ek}^{\mathrm{u}}$ - /*heuk- «бачити».

Прамовні відповідники Алт *ok ${ }^{\mathrm{u}} \mathrm{i}-$, Двн.-грец. *ok ${ }^{\mathrm{u}} \mathrm{ie}$ в проєкції до IЄ *h" ${ }^{\mathrm{u}} \mathrm{k}^{\mathrm{u}}-/$ *heuk- дають змогу зафіксувати фонетичні процеси вокалізму: 
1) процеси за піднесенням: середній $\left({ }^{*} \mathrm{o}\right.$ : Алт ${ }^{*} \mathbf{o k}^{\mathrm{u}} \mathrm{i}-$, Двн.-грец. $\left.{ }^{*} \mathbf{o k}{ }^{\mathrm{u}} \mathrm{i} \mathrm{e}\right)$ зсув; 2) процеси за рядом: фіксуємо задній (*o: Алт *ok ${ }^{\mathrm{u}} \mathrm{i}-$, Двн.грец. *ok ${ }^{\mathrm{u}}$ ie) зсув; 3) процеси лабіалізації/делабіалізації: фіксуємо лабіалізацію (*o: Алт *ok ${ }^{\mathrm{u}} \mathrm{i}$, Двн.-грец. ${ }^{*} \mathrm{k}^{\mathrm{u}} \mathrm{i}$ e); фонетичні процеси консонантизму: 1) процеси за місцем творення: фіксуємо веляризацію $\quad\left({ }^{*} \mathrm{k}:\right.$ албанський $\quad{ }^{*} \mathbf{k}^{\mathrm{u}} \mathrm{i}-, \quad$ давньогрецький $\left.\quad{ }^{*} \mathbf{k}^{\mathrm{u}}{ }^{\mathrm{u}} \mathrm{e}\right)$; 2) процеси за участю голосу й шуму: фіксуємо глухість (*k: албанський *ok ${ }^{\mathrm{u}} \mathrm{i}-$, давньогрецький $*_{\mathrm{ok}}^{\mathrm{u}} \mathrm{ie}$ ); процеси: 1) закон про двохелементну структуру, 2) закон про закритий склад (Алб *ok ${ }^{\mathrm{u}}-$ - Алб *VC-, Двн.-грец. *ok ${ }^{\mathrm{u}} \mathrm{je}$ - Двн.-грец. *VC-); семантичні процеси: 1) APX «орган зору»: Алб *ok ${ }^{\mathrm{u}} \mathrm{i}-$ «око», Двн.-грец. *ok"ịe “око”; 2) АРX «зорова здатність»: Алб *ok ${ }^{\mathrm{u}} \mathrm{i}$ «бачити», Двн.-грец. *ok ${ }^{\mathrm{u}}$ ịe «бачити».

\section{2. Діахронічна верифікація ступенів споріднення ностратичних мов} за тріадою тип - вид - відношення

Друга стадія - діахронічна верифікація (далі - ДВ) ступенів споріднення ностратичних мов за тріадою: 1) тип: а) дивергентноконвергентний, б) конвергентно-дивергентний; 2) вид: а) близький, б) далекий); 3) відношення: а) тривіальні, б) помітні, в) конвенціональні 3 фіксацією ступеня переважання всередині кожного 3 них. ДВ ступенів споріднення ностратичних мов буде здійснюватися за допомогою двох математичних алгоритмів: за формулою Г.В. Раушенбаха $^{5}$ - для фіксації типу; за формулою Т. Соренсена - для фіксації виду; і одного електронного алгоритму В.І. Левенштейна. За результатами трьох алгоритмів будуть виявлені відношення між відповідниками, а отже, і мовними сім'ями і т. ін.

Перший етап - ДВ ступенів споріднення ностратичних мов за установкою тип: а) дивергентно-конвергентний, б) конвергентнодивергентний буде виконана за формулою Г.В. Раушенбаха:

$$
S_{1}=\frac{a+d}{a+b+c+d},
$$

де а - набір процесів, що не фіксуються у X і Y одночасно, d - набір процесів, що збігаються, b (або с) - набір процесів, що фіксуються в X, але не фіксуються в Y (або навпаки). Сума $(\mathrm{a}+\mathrm{b}+\mathrm{c}+\mathrm{d})$ дорівнює загальному набору процесів $\mathrm{n}$.

\footnotetext{
${ }^{5}$ Раушенбах Г.В. Меры близости и сходства. Анализ нечисловой информации в социологических исследованиях. Москва : Наука, 1985. С. 169-203.
} 
Зважаючи на те, що ностратичний матеріал не відображає такий набір процесів, що не фіксуються у X і Y одночасно, тому змінну а вилучаємо з цієї формули і уточнюємо її з такими змінними:

$$
S=\frac{c}{a+b+c},
$$

де a (або b) - набір процесів, що фіксуються в X, але не фіксуються в Y (або навпаки), с - набір процесів, що збігаються в X i Y. Сума $(\mathrm{a}+\mathrm{b}+\mathrm{c})$ дорівнює загальному набору процесів $\mathrm{n}$.

На першій процедурі першого етапу визначаємо набір фонологічних, морфонологічних і семантичних переходів, представлених у матриці, змодельованої під час першої стадії ДВ, для макро- i мікрорівнів відповідно до трьох (3) змінних: а (або b) - набір процесів, що фіксуються в $\mathrm{X}$, але не фіксуються в Y (або навпаки), с - набір процесів, що збігаються в X і Y.

На макрорівні по вертикалі представлено три пари архетипів: 1) НА *HuКа «око, бачити» і Алт *uka- «помічати, розуміти»; 2) НА *HuKa «око, бачити» i Афp *Hwq- «знати»; 3) НА *HuKa «око, бачити» i IC * $\mathrm{h}^{\mathrm{u}} \mathrm{ek}{ }^{\mathrm{u}}-/{ }^{*}$ heuk- «око, бачити», для яких обчислюємо набір процесів відповідно до трьох змінних.

НА *НиКа «око, бачити» і Алт *uka- «помічати, розуміти» відображають такі процеси відповідно до трьох змінних:

Змінна а (або b) = 4 процесам, адже:

НА *НиКа «око, бачити» відображає фонетичні процеси консонантизму: 1) процеси за місцем творення: початок ЗМС: глоталізація - один процес; 2) процеси за участю голосу й шуму: початок ЗМС: глухість - один процес (*h: HA *HuKa); морфонологічні процеси: 1) закон про трьохелементну структуру 3МС - один процес (HA *HuK- - HA *CVC-); семантичні процеси: 1) APX «орган зору»один процес (НА *НuКа «око»).

Змінна с $=20$ процесам, адже:

НА *НиКа “око, бачити” і Алт *ukа- «помічати, розуміти» відображають спільні фонетичні процеси вокалізму: 1) процеси за піднесенням: початок ЗМС: верхній зсув; кінець ЗМС: нижній зсув чотири процеси; 2) процеси за рядом: початок ЗМС: задній зсув; кінець ЗМС: середній зсув - чотири процеси; 3) процеси лабіалізації/делабіалізації: початок ЗМС: лабіалізація; кінець ЗМС: делабіалізація - чотири процеси (початок ЗМС: *u: НА *НuКа, Алт *uka-; кінець 3МС: *a: НА *НuКа, Алт *uka-); фонетичні процеси консонантизму: 1) процеси за місцем творення: кінець ЗМС: веляризація - два процеси; 2) процеси за участю голосу й шуму: 
кінець ЗМС: глухість - два процеси (*k: НА НuКа, Алт *uka-); морфонологічні процеси: 1) закон про закритий склад - два процеси (HA *HuK- - HA *CVC-, Алт *uk- - Алт *VC-); семантичні процеси: APX «зорова здатність» - два процеси (НА *НuК̆а «бачити», Алт *uka- «помічати»).

НА *НuКа «око, бачити» і Афр *Нwq- «знати» відображають такі процеси відповідно до трьох змінних:

Змінна а (або b) $=7$ процесам, адже:

НА *НuК̆а «око, бачити» відображає фонетичні процеси вокалізму: 1) процеси за піднесенням: початок ЗМС: верхній зсув; кінець ЗМС: нижній зсув - два процеси; 2) процеси за рядом: початок ЗМС: задній зсув; кінець ЗМС: середній зсув - два процеси; 3) процеси лабіалізації/делабіалізації: початок ЗМС: лабіалізація; кінець ЗМС: делабіалізація - два процеси (початок ЗМС: *u: НА *НuКа; кінець 3МС: *a: НА *НuКа); семантичні процеси: АРX «орган зору»- один процес (НА *НuКа «око»).

Змінна с = 11 процесам, бо:

НА *НuКа «око, бачити» і Афр *Hwq- «знати» відображають спільні фонетичні процеси консонантизму: 1) процеси за місцем творення: початок ЗМС: глоталізація; кінець ЗМС: веляризація чотири процеси; 2) процеси за участю голосу й шуму: початок ЗМС: глухість; кінець ЗМС: глухість - чотири процеси (початок 3МC: *h: HА *HuKa, Афp *Hwq-; кінець 3MC: *k: HuKa; *q: *Hwq-); морфонологічні процеси: 1) закон про трьохелементну структуру два процеси; 2) закон про закритий склад - два процеси (HA *HuK- - HA *CVC-, Aфp *Hwq- - Aфp *CCC-).

НА *НиКа «око, бачити» і IC *h"ek"- / *heuk- «око, бачити» відображають такі процеси відповідно до трьох змінних:

Змінна а (або b) = 6 процесам, адже:

НА *НиКа «око, бачити» відображає фонетичні процеси вокалізму: 1) процеси за піднесенням: початок ЗМС: верхній зсув; кінець ЗМС: нижній зсув - два процеси; 2) процеси за рядом: початок ЗМС: задній зсув; кінець ЗМС: середній зсув - два процеси; 3) процеси лабіалізації/делабіалізації: початок ЗМС: лабіалізація; кінець ЗМС: делабіалізація - два процеси (початок ЗМС: *u: НА *НuКа; кінець 3MC: *a: HA *HuKa).

Змінна $\mathrm{c}=12$ процесам, адже:

НА *НuКа «око, бачити» i IG *h"ek"-/*heuk- «око, бачити» відображають спільні фонетичні процеси консонантизму: 1) процеси за місцем творення: початок ЗМС: глоталізація; кінець ЗМС: веляризація - чотири процеси; 2) процеси за участю голосу й шуму: початок ЗМС: глухість; кінець ЗМС: глухість - чотири процеси

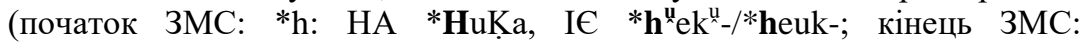


*k: HA НuKa, IC *h" ${ }^{\mathrm{u}} \mathbf{k}^{\mathrm{u}}-/{ }^{*}$ heuk-); семантичні процеси: 1) APX «орган зору» - два процеси (НА *НuКа «око», IC *hüek ${ }^{\mathrm{u}}-/ *$ heuk- «око»); 2) АРX «зорова здатність» - два процеси (НА *НuКа «бачити», IC * $h^{\mathrm{u}} \mathrm{ek}^{\mathrm{u}}-/ *$ heuk- «бачити»).

На макрорівні по горизонталі представлено три пари архетипів: 1) Алт *uka- «помічати, розуміти» і Афр *Hwq- «знати»; 2) Алт *uka«помічати, розуміти» і IC *h" $\mathrm{ek}^{\mathrm{u}}-/{ }^{*}$ heuk- «око, бачити»; 3) Афp *Hwq«знати» i IC *h" $\mathrm{ek}^{\mathrm{u}}-/ *$ heuk- «око, бачити», для яких окреслюємо набір процесів відповідно до трьох змінних.

Алт *uka- «помічати, розуміти» і Афp *Hwq- «знати» відображають такі процеси відповідно до трьох змінних:

Змінна а (або b) = 7 процесам, адже:

Алт *uka- «помічати, розуміти» відображає фонетичні процеси вокалізму: 1) процеси за піднесенням: початок ЗМС: верхній зсув; кінець ЗМС: нижній зсув - два процеси; 2) процеси за рядом: початок ЗМС: задній зсув; кінець ЗМС: середній зсув - два процеси; 3) процеси лабіалізації/делабіалізації: початок ЗМС: лабіалізація; кінець ЗМС: делабіалізація - два процеси (початок ЗМС: *u: Алт *uka-; кінець 3МC: *a: Алт *uka-); морфонологічні процеси: 1) закон про двохелементну структуру - один (1) процес (Алт *uk- - Алт *VC-).

Змінна с $=8$ процесам, адже:

Алт *uka- «помічати, розуміти» і Афр *Hwq- «знати» відображають спільні фонетичні процеси консонантизму: 1) процеси за місцем творення: веляризація - два процеси; 2) процеси за участю голосу й шуму: глухість - два процеси (*k: Алт *uka-; *q: *Hwq-); морфонологічні процеси: 1) закон про закритий склад - два процеси (Алт *uk- - Алт *VC-, Афp *Hwq- - Aфp *CCC-); семантичні процеси: АPX «розумова здітність» - два процеси (Алт *uka- «розуміти», Афр *Hwq- «знати»).

Алт *uka- «помічати, розуміти» i IG *h"ek"-/*heuk- «око, бачити» відображають такі процеси відповідно до трьох змінних:

Змінна а (або b) = 5 процесам, адже:

Алт *uka- «помічати, розуміти» відображає фонетичні процеси вокалізму: 1) процеси за піднесенням: початок ЗМС: верхній зсув - один процес; 2) процеси за рядом: початок ЗМС: задній зсув - один процес; 3) процеси лабіалізації/делабіалізації: початок ЗМС: лабіалізація - один процес (*u: Алт *uka-); морфонологічні процеси: 1) закон про двохелементну структуру - один процес (Алт *uk- - Алт *VC-).

Змінна с $=8$ процесам, адже:

Алт *uka- «помічати, розуміти» і IC *h"ek"-/*heuk- «око, бачити» відображають спільні фонетичні процеси консонантизму:1) процеси за місцем творення: веляризація - два процеси; 2) процеси за участю голосу й шуму: глухість - два процеси (*k: Алт *uka-, IC *h" ${ }^{\mathrm{u}} \mathbf{k}^{\mathrm{u}}-/{ }^{*}$ heuk-); морфонологічні процеси: 1) закон про закритий склад - два процеси 
(Алт *uk- - Алт *VC-, IC *hek $\mathrm{h}^{\mathrm{u}}$-/*heuk- - IC *CVC-/*CVVC-); семантичні процеси: 1) APX «зорова здатність» - два процеси (Алт *uka«помічати», IC *hek $\mathrm{h}^{\mathrm{u}}-/ *$ heuk- «бачити»).

Афр *Hwq- «знати» i IC *h"ek"-/*heuk- «око, бачити» відображають такі процеси відповідно до трьох змінних:

Змінна а (або b) = 3 процесам, адже:

Афр *Hwq- «знати» відображає фонетичні процеси консонантизму: 1) процеси за місцем творення: середина ЗМС: наявність білабіального ${ }^{*} \mathrm{~W}-$ один процес; 2) процеси за участю голосу й шуму: середина ЗМС: дзвінкість - один процес $\left({ }^{*} \mathrm{w}:\right.$ Афp *Hwq-); семантичні процеси: АPX «розумова здатність» - один (1) процес (Афр *Нwq- «знати»).

Змінна $\mathrm{c}=12$ процесам, адже:

Aфр *Hwq- «знати» і IE *h"ek"-/*heuk- «око, бачити» відображають спільні фонетичні процеси консонантизму: 1) процеси за місцем творення: початок ЗМС: глоталізація; кінець ЗМС: веляризація - чотири процеси; 2) процеси за участю голосу й шуму: початок ЗМС: глухість; кінець 3МС: глухість - чотири процеси (початок 3МC: *h: Aфp *Hwq-, IC

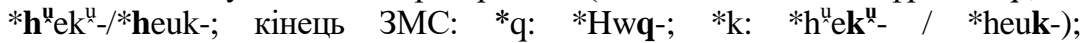
морфонологічні процеси: 1) закон про трьохелементну структуру - два процеси; 2) закон про закритий склад - два процеси (Афр *Нwq- - Афр *CCC-, IC *h" ek ${ }^{\mathrm{u}}-/ *$ heuk- - IC *CVC-/*CVVC-).

Друга процедура першого етапу передбачала обчислення зв'язків величин на макро- i мікрорівнях у пунктах а) і б), які допоможуть припустити про один із типів споріднення ностратичних мов 3 референтними значеннями: а) дивергентно-конвергентний (від 0 до 0,49) або б) конвергентно-дивергентний (від 0,5 до 1,0).

Таблиця 1

Результати обчислення фонологічної, морфонологічної і семантичної структур ностратичних величин (за алгоритмом Г.В. Раушенбаха)

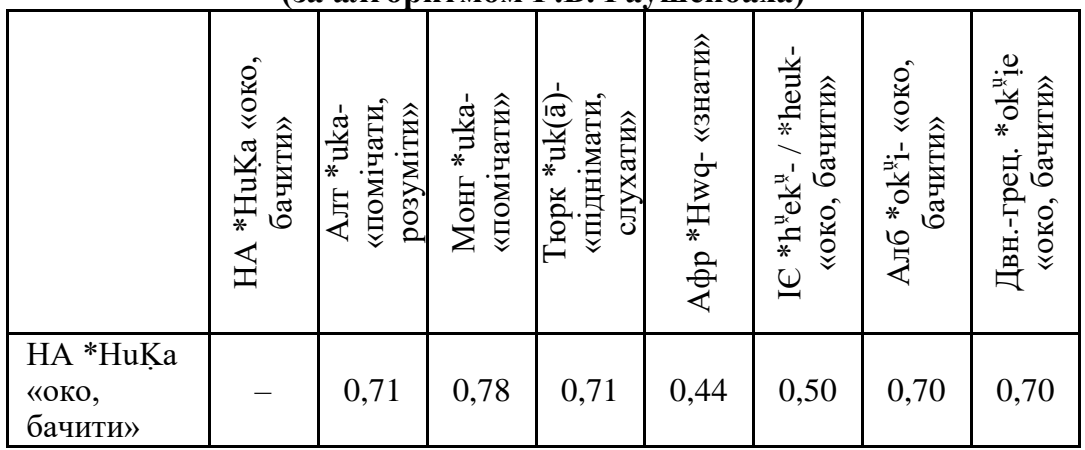


Закінчення таблиці 1

\begin{tabular}{|c|c|c|c|c|c|c|c|c|}
\hline & 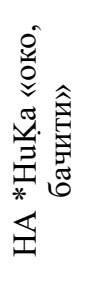 & 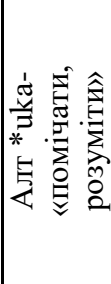 & 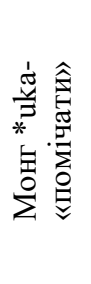 & 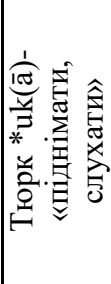 & 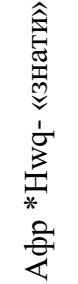 & 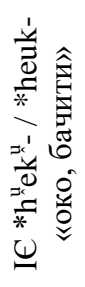 & 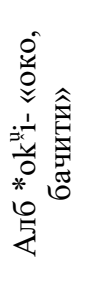 & 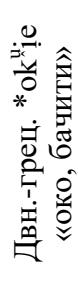 \\
\hline $\begin{array}{l}\text { Алт *uka- } \\
\text { «помічати, } \\
\text { розуміти» }\end{array}$ & 0,71 & - & 0,92 & 0,85 & 0,36 & 0,44 & - & - \\
\hline $\begin{array}{l}\text { Монг *uka- } \\
\text { «помічати» }\end{array}$ & 0,78 & 0,92 & - & 1,00 & - & - & - & - \\
\hline $\begin{array}{l}\text { Тюрк } \\
\text { *uk(ā)- } \\
\text { «піднімати, } \\
\text { слухати» }\end{array}$ & 0,71 & 0,85 & 1,00 & - & - & - & - & - \\
\hline $\begin{array}{l}\text { Афp *Hwq- } \\
\text { «знати» }\end{array}$ & 0,44 & 0,36 & - & - & - & 0,67 & - & - \\
\hline $\begin{array}{l}\mathrm{I} \epsilon^{*} \mathrm{~h}^{\mathrm{u}} \mathrm{ek}^{\mathrm{u}}-\text { I } \\
\text { *heuk- } \\
\text { «око, } \\
\text { бачити» }\end{array}$ & 0,50 & 0,44 & - & - & 0,67 & - & 0,63 & 0,63 \\
\hline $\begin{array}{l}\text { Алб *ok } \text { ok }^{\mathrm{u}}- \\
\text { «око, } \\
\text { бачити» }\end{array}$ & 0,70 & - & - & - & - & 0,63 & - & 1,00 \\
\hline $\begin{array}{l}\text { Двн.-грец. } \\
\text { *ok }{ }^{\mathrm{u}} \text { ำ } \\
\text { «око, } \\
\text { бачити» }\end{array}$ & 0,70 & - & - & - & - & 0,63 & 1,00 & - \\
\hline
\end{tabular}

Другий етап - ДВ ступенів споріднення ностратичних мов за установкою вид: а) близький або б) далекий буде відбуватися за допомогою: 1) електронного алгоритму В.І. Левенштейна - для обчислення морфонологічної структури двох і більше величин; 2) математичного алгоритму T. Соренсена - для обчислення семантичної структури двох і більше величин.

На першій процедурі другого етапу застосовуємо електронний калькулятор, представлений в режимі Інтернет, і виконуємо таку послідовність дій: офіційний вебсайт «Онлайн калькуляторы» (URL: https://calculatorium.ru/text/levenshtein-distance) - опція «Расстояние Левенштейна», де подано два поля: перше поле - для першої величини, 
друге поле - для другої величини, до яких заносимо дві величини: морформи архетипів і натискаємо опцію «Вычислить расстояние Левенштейна» (див. рис. 1). Усі результати обчислення заносимо до таблиці (див. табл. 2).

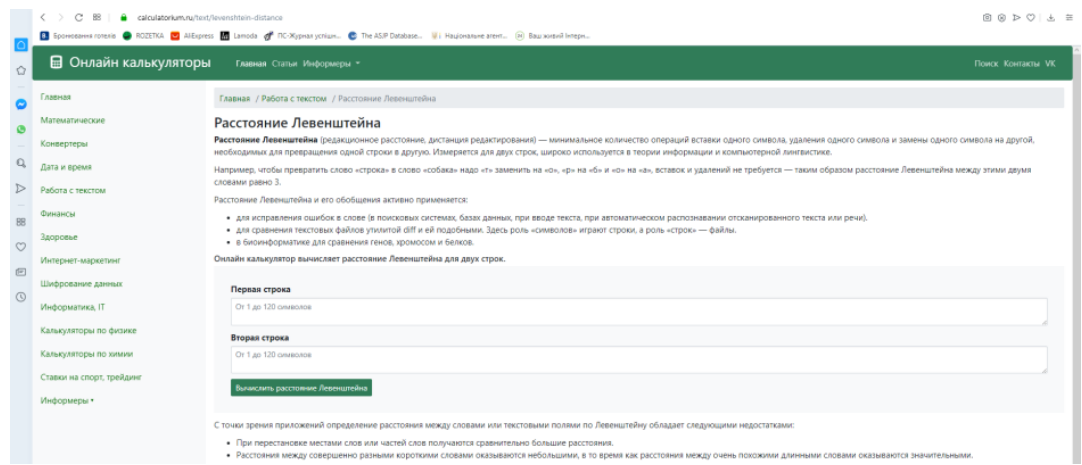

Рис. 1. Онлайн калькулятор для обчислення величин морфонологічної структури ностратичних етимонів

Таблиця 2

Результати обчислення морфонологічної структури ностратичних величин (за алгоритмом В.І. Левенштейна)

\begin{tabular}{|c|c|c|c|c|c|c|c|c|}
\hline & 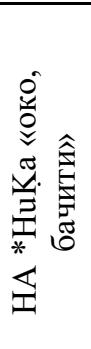 & 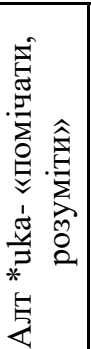 & 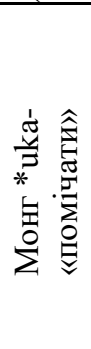 & 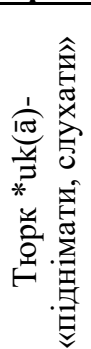 & 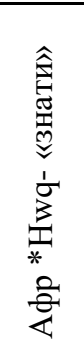 & 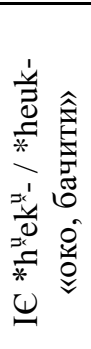 & 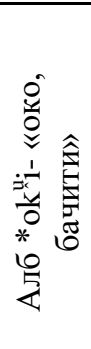 & 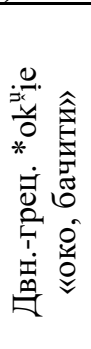 \\
\hline $\begin{array}{l}\text { НА *НuКа } \\
\text { «око, } \\
\text { бачити» }\end{array}$ & - & 1,00 & 1,00 & 1,00 & 3,00 & 2,00 & 3,00 & 4,00 \\
\hline $\begin{array}{l}\text { Алт *uka- } \\
\text { «помічати, } \\
\text { розуміти» }\end{array}$ & 1,00 & - & 0,00 & 0,00 & 4,00 & 3,00 & - & - \\
\hline $\begin{array}{l}\text { Монг *uka- } \\
\text { «помічати» }\end{array}$ & 1,00 & 0,00 & - & 0,00 & - & - & - & - \\
\hline
\end{tabular}


Закінчення таблиці 2

\begin{tabular}{|c|c|c|c|c|c|c|c|c|}
\hline & 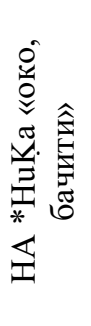 & 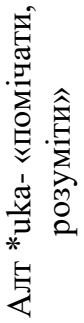 & 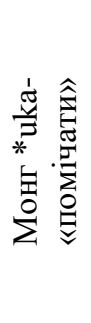 & 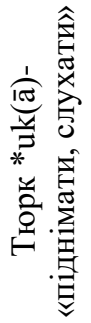 & 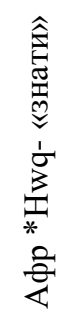 & 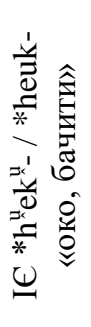 & 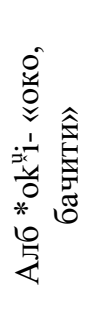 & 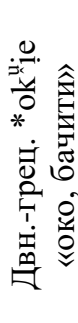 \\
\hline $\begin{array}{l}\text { Tюрк } \\
\text { *uk(a) } \\
\text { «піднімати, } \\
\text { слухати» } \\
\end{array}$ & 1,00 & 0,00 & 0,00 & - & - & - & - & - \\
\hline $\begin{array}{l}\text { Афр *Hwq- } \\
\text { «знати» }\end{array}$ & 3,00 & 4,00 & - & - & - & 2,00 & - & - \\
\hline $\begin{array}{l}\mathrm{I} \epsilon^{*} \mathrm{~h}^{\mathrm{u}} \mathrm{ek}^{\mathrm{u}}-\text { I } \\
\text { *heuk- } \\
\text { «око, } \\
\text { бачити» }\end{array}$ & 2,00 & 3,00 & - & - & 2,00 & - & 3,00 & 4,00 \\
\hline $\begin{array}{l}\text { Алб *ok }{ }^{\mathrm{u}} \mathrm{i}- \\
\text { «око, } \\
\text { бачити» }\end{array}$ & 3,00 & - & - & - & - & 3,00 & - & 1,00 \\
\hline $\begin{array}{l}\text { Двн.-грец. } \\
\text { *ok }{ }^{\mathrm{u}} \text { ie } \\
\text { «око, } \\
\text { бачити» }\end{array}$ & 4,00 & - & - & - & - & 4,00 & 1,00 & - \\
\hline
\end{tabular}

На другій процедурі другого етапу застосовуємо математичний алгоритм Т. Соренсена для обчислення семантичної відстані/дистанції ностратичних величин:

$$
D=1-\frac{2 \cdot q}{A+B},
$$

де q позначає спільні значення, а $\mathrm{A}+\mathrm{B}-$ суму дефініцій зіставлюваних значень компарантів у заданій кількості (див. табл. 3).

На третій процедурі другого етапу поєднуємо результати, одержані під час першої i другої процедур, які допоможуть установити залежність/зв'язок величин на макро- і мікрорівнях у пунктах а) і б), тобто припустити про один із видів споріднення ностратичних мов: а) близький (3,00 і вище), б) далекий (3,00 і нижче) (див. табл. 4). 
Таблиця 3

Результати обчислення семантичної структури ностратичних величин (за алгоритмом Т. Соренсена)

\begin{tabular}{|c|c|c|c|c|c|c|c|c|}
\hline & 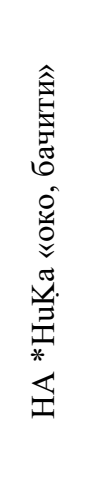 & 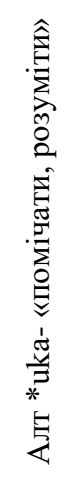 & 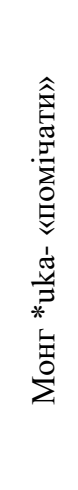 & 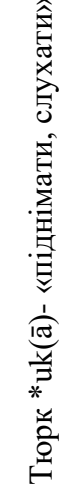 & 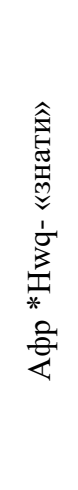 & 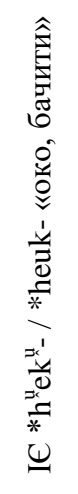 & 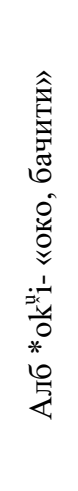 & 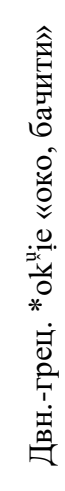 \\
\hline $\begin{array}{l}\text { HA *HuKa } \\
\text { «око, } \\
\text { бачити» }\end{array}$ & - & 0,50 & 0,33 & 1,00 & 1,00 & 0,00 & 0,00 & 0,00 \\
\hline $\begin{array}{l}\text { Алт *uka- } \\
\text { «помічати, } \\
\text { розуміти» }\end{array}$ & 0,50 & - & 0,33 & 0,00 & 0,33 & 0,50 & - & - \\
\hline $\begin{array}{l}\text { Монг *uka- } \\
\text { «помічати» }\end{array}$ & 0,33 & 0,33 & - & 0,00 & - & - & - & - \\
\hline $\begin{array}{l}\text { Тюрк } \\
\text { *uk(ā)- } \\
\text { «піднімати, } \\
\text { слухати» }\end{array}$ & 1,00 & 0,00 & 0,00 & - & - & - & - & - \\
\hline $\begin{array}{l}\text { Афр *Hwq- } \\
\text { «знати» }\end{array}$ & 1,00 & 0,33 & - & - & - & 0,00 & - & - \\
\hline $\begin{array}{l}\text { IC *h" }{ }^{\mathrm{u}} \mathrm{ek}^{\mathrm{u}}-\text { I } \\
\text { *heuk- } \\
\text { «око, } \\
\text { бачити» } \\
\end{array}$ & 0,00 & 0,50 & - & - & 0,00 & - & 0,00 & 0,00 \\
\hline $\begin{array}{l}\text { Алб *ok }{ }^{\mathrm{u}} \mathrm{i}- \\
\text { «око, } \\
\text { бачити» }\end{array}$ & 0,00 & - & - & - & - & 0,00 & - & 0,00 \\
\hline $\begin{array}{l}\text { Двн.-грец. } \\
\text { *ok }{ }^{\mathrm{u}} \mathrm{ie} \\
\text { «око, } \\
\text { бачити» }\end{array}$ & 0,00 & - & - & - & - & 0,00 & 0,00 & - \\
\hline
\end{tabular}


Таблиця 4

Результати обчислення морфонологічної і семантичної структур ностратичних величин (за алгоритмами В.І. Левенштейна і Т. Соренсена)

\begin{tabular}{|c|c|c|c|c|c|c|c|c|}
\hline & 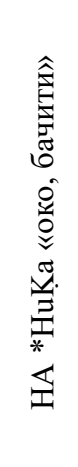 & 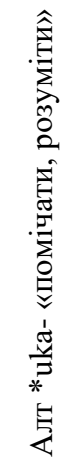 & 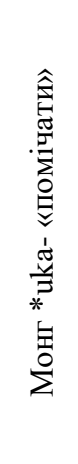 & 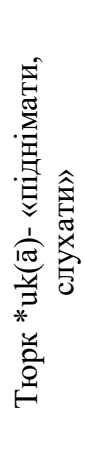 & 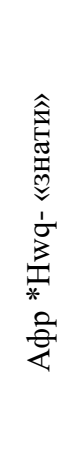 & 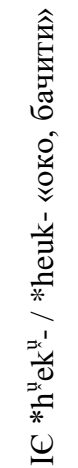 & 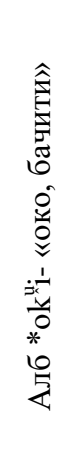 & 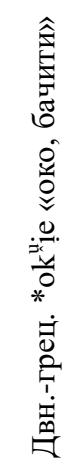 \\
\hline $\begin{array}{l}\text { НА *HuKa } \\
\text { «око, } \\
\text { бачити» }\end{array}$ & - & 1,50 & 1,33 & 2,00 & 4,00 & 2,00 & 3,00 & 4,00 \\
\hline $\begin{array}{l}\text { Алт *uka- } \\
\text { «помічати, } \\
\text { розуміти» }\end{array}$ & 1,50 & - & 0,33 & 0,00 & 3,33 & 3,50 & - & - \\
\hline $\begin{array}{l}\text { Монг *uka- } \\
\text { «помічати» }\end{array}$ & 1,33 & 0,33 & - & 0,00 & - & - & - & - \\
\hline $\begin{array}{l}\text { Тюрк } \\
\text { *uk(ā)- } \\
\text { «піднімати, } \\
\text { слухати» }\end{array}$ & 2,00 & 0,00 & 0,00 & - & - & - & - & - \\
\hline $\begin{array}{l}\text { Афр *Hwq- } \\
\text { «зати» }\end{array}$ & 4,00 & 3,33 & - & - & - & 2,00 & - & - \\
\hline $\begin{array}{l}\mathrm{IC}{ }^{*} \mathrm{~h}^{\mathrm{u}} \mathrm{ek}^{\mathrm{u}}-\text { I } \\
\text { *heuk- } \\
\text { «око, } \\
\text { бачити» }\end{array}$ & 2,00 & 3,50 & - & - & 2,00 & - & 3,00 & 4,00 \\
\hline $\begin{array}{l}\text { Алб *ok"u- } \\
\text { «око, } \\
\text { бачити» }\end{array}$ & 3,00 & - & - & - & - & 3,00 & - & 1,00 \\
\hline $\begin{array}{l}\text { Двн.-грец. } \\
\text { *ok }{ }^{\mathrm{u}}{ }^{\mathrm{p}} \mathrm{e} \\
\text { «око, } \\
\text { бачити» }\end{array}$ & 4,00 & - & - & - & - & 4,00 & 1,00 & - \\
\hline
\end{tabular}




\section{ВИСНОВКИ}

Виконана діахронічна верифікація Ностр етимона *НuКа «око, бачити» дає підстави для попередніх науково-гіпотетичних припущень про ступені масового споріднення між ностратичними мовами, для яких він був реконструйований. Одержані результати верифіковані шляхом залучення математичних обчислень, зокрема алгоритму B.I. Левенштейна (для виявлення морфонологічних показників), алгоритму T. Соренсена (для семантичних показників), що сприяли установленню генетичного чи контактного типів споріднення, їхніх видів і відношень.

У результаті паралельного обчислення фонетичних, морфонологічних і семантичних переходів Ностр *НuКа «око, бачити» в ностратичних мовах виявлено дивергентний розвиток між Ностр *HuKa «око, бачити» i Aфp *Hwq- «знати» - 0,44 (кількість закономірностей: морфонологічних - 3,00, семантичних - 1,00), дивергентно-конвергентний - між Ностр *НuКа «око, бачити» і IC *h $\mathrm{h}^{\mathrm{u}} \mathrm{k}^{\mathrm{u}}$ - / *heuk- «око, бачити» - 0,50 (кількість закономірностей: морфонологічних - 2,00, семантичних - 0,00$)$ й імовірно конвергентно-дивергентний - між Ностр *НuКа «око, бачити» і Алт *uka- «помічати, розуміти» - 0,71 (кількість закономірностей: морфонологічних $-1,00$, семантичних $-0,50)$.

Найбільш близький ступінь споріднення фіксуємо між Афp *Hwq«знати» i Алт *uka- «помічати, розуміти», що відповідає дивергентно-конвергентному розвитку $(=4,33)$ як факт збереження їхніх генетичних зв'язків 3 ностратичною прамовою, що відображено переважно в діахронічних переходах: морфонологічних $(=4,00)$ : 1) глотальний *h Афp *Hwq- занепав в Алт *uka-; 2) білабіальний ${ }^{*} \mathrm{w}$ Афр *Hwq- перейшов у вокалічний заднього ряду *u в Алт *uka-; 3 ) увулярний *q Афp *Hwq- - у велярний *k в Алт *uka-; 4) нульовий ступінь (Афр *Hwq-) - вокалічний центрального ряду (Алт *uka-) i меншою мірою в семантичних зсувах $(0,33)$ : на базі значення «розумова здатність» Афр *Hwq- «знати» розвинулося значення «зорова здатність» в Алт *uka- «помічати».

Більшою мірою розійшлися у своїх генетичних зв'язках $\mathbf{I C}$ *h"ek"*heuk- «око, бачити» i Алт *uka- «помічати, розуміти» $(=3,50)$, що дає підстави припустити про віддалений ступінь споріднення між цими мовами, а також переважно дивергентноконвергентний розвиток, що відображено в діахронічних переходах як морфонологічних (= 3,00): 1) глотальний *h I€ *h" $\mathrm{ek}^{\mathrm{u}}-/ *$ heuk- занепав в Алт *uka-; 2) вокалічний переднього ряду *e/*eu IC *hu ek $^{\mathrm{u}}-/ *$ heukперейшов у вокалічний заднього ряду *u в Алт *uka-; 3) нульовий ступінь (IC * $\mathrm{h}^{\mathrm{u}} \mathrm{ek}^{\mathrm{u}}-/ *$ heuk-) - вокалічний центрального ряду 
*a (Алт *uka-), так і семантичних $(0,50)$ : значення «орган зору» IC

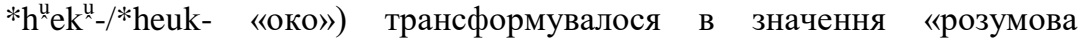
здатність» в Алт *uka- «розуміти». Ці показники засвідчують більш віддалений ступінь споріднення між цими ностратичними мовами.

Більш далекий ступінь споріднення демонструють Афр *Hwq- й IC

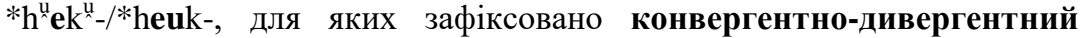
розвиток (ймовірно, в тому числі за рахунок контактів), що простежується меншою мірою в морфонологічних зсувах (= 2,00): 1) білабіальний $*_{\mathrm{w}}(\mathrm{A \phi p} * \mathrm{Hwq}-)$ перейшов у вокалічний переднього ряду *e/*eu (IC *hu $\mathrm{ek}^{\mathrm{u}}-/ *$ heuk-); 2) увулярний *q (Афp *Hwq-) у велярний $* \mathrm{k}$ (I€ $\left.{ }^{*} \mathrm{~h}^{\mathrm{u}} \mathrm{e} \mathrm{k}^{\mathrm{u}}-/{ }^{*} \mathrm{heuk}-\right)$ зі збереженням ініціалії $* \mathrm{~h}$ i у зрушеннях семантичних: значення «розумова здатність» Афр *Hwq«знати» не адаптувалося загалом в IE * ${ }^{\mathrm{u}} \mathrm{ek}^{\mathrm{u}}-/ *$ heuk- «око». На підставі цих обчислень припускаємо далекий ступінь споріднення між цими мовами.

\section{АНОТАЦІЯ}

У статті запропоновано методологічний алгоритм діахронічної верифікації фонологічних, граматичних і семантичних переходів ностратичного етимону *НuKa «око, бачити» 3 метою фіксації ступенів споріднення ностратичних мов за тріадою: 1) тип: а) дивергентноконвергентний, б) конвергентно-дивергентний; 2) вид: а) близький, б) далекий); 3) відношення: а) тривіальні, б) помітні, в) конвенціональні за допомогою двох математичних алгоритмів: за формулою Г.В. Раушенбаха - для фіксації типу; за формулою Т. Соренсена - для фіксації виду; і одного електронного алгоритму В.І. Левенштейна.

Ключові процедурні моменти діахронічної верифікації ступенів споріднення ностратичних мов було здійснено на трьох послідовних рівнях, зокрема на макрорівні за: а) вертикальним одновекторним напрямом (між ностратичним етимоном і етимоном(-и) на рівні сім'ї); б) горизонтальним багатовекторним напрямом (між етимонами на рівні сім’і); на мікрорівні за: а) вертикальним одновекторним напрямом прамовного рівня (між етимоном на рівні сім'ї і етимоном(-и) на рівні груп(-и)); б) горизонтальним багатовекторним напрямом прамовного рівня (між етимонами на рівні груп); в) вертикальним одновекторним напрямом мовного рівня (між етимоном на рівні сім'ї i/aбо етимоном(-и) на рівні груп(-и) і мовним(-и) відповідником(-ами); г) горизонтальним багатовекторним напрямом мовного рівня (між мовними відповідниками); на наскрізному рівні за: а) вертикальним № 1 (між ностратичним етимоном i етимоном(-ами) на рівні груп(-и); б) вертикальним № 2 (між ностратичним етимоном i мовними відповідниками). 


\section{ЛIТЕРАТУРА}

1. Дронова Л.П. Синхрония и диахрония: отложенная встреча? Вестник Томского государственного университета. Филология. Томск, 2009. № 3(7). C. 116-123.

2. Иллич Свитыч В.М. Опыт сравнения ностратических языков (семито-хамитский, картвельский, индоевропейский, уральский, дравидийский, алтайский) / под ред. В.А. Дыбо. Москва, 1971. Т. 1. $414 \mathrm{c}$.

3. Климов Г.А. Реконструкция и диахроническая интерпретация в компаративистике. Вопросы языкознания. Москва, 1988. № 3. С. 9-16.

4. Раушенбах Г.В. Меры близости и сходства. Анализ нечисловой информации в сочиологических исследованиях. Москва : Наука, 1985. C. 169-203.

5. Семереньи О. Введение в сравнительное языкознание. Москва, 1980. C. 13.

6. Философский энииклопедический словарь/ ред.-сост. Е.Ф. Губский и др. Москва : ИНФРА-М, 2012. 570 с.

\section{Information about the authors:} Korolyova A. V., Doctor of Sciences (Linguistics), Professor, Vice-Rector on Research Kyiv National Linguistic University 73, Velyka Vasylkivska str., Kyiv, 03680, Ukraine

Kapranov Ya. V., Candidate of Sciences (Linguistics), Associate Professor, Doctoral Student in the Professor G. G. Pocheptsov Department of Germanic and Finno-Ugric Philology Kyiv National Linguistic University 73, Velyka Vasylkivska str., Kyiv, 03680, Ukraine 